\title{
Dimensioning of reservoirs for semiarid regions using synthetic series
}

\author{
Priscila R. Vieira ${ }^{1}$, Fernando F. Pruski ${ }^{1}$ \& José R. C. Souza ${ }^{2}$ \\ ${ }^{1}$ Universidade Federal de Viçosa/Departamento de Engenharia Agrícola. Viçosa, MG, Brasil. E-mail: priscilaramos255@hotmail.com \\ (Corresponding author) - ORCID: 0000-0001-7978-1177; ffpruski@ufv.br - ORCID: 0000-0002-7957-6402 \\ ${ }^{2}$ Instituto Federal do Sudeste de Minas Gerais/Departamento Acadêmico de Ciência da Computação. Rio Pomba, MG, Brasil. E-mail: josé. \\ castro@ifsudestemg.edu.br - ORCID: 0000-0003-4426-2996
}

\begin{abstract}
The lack of fluviometric data for hydrographic basins affects the estimates of capacity of regularization reservoirs, important to meet water seasonal demands. The objective of this study was to evaluate the performance of methodologies based on synthetic series (SS) of streamflow for the dimensioning of regularization reservoirs in the Jequitinhonha River Basin, Brazil. The reservoir capacity (RC) was estimated with and without the association to return period, using different long-term mean streamflow rates, SS from the observed data, and estimated data by the streamflow regionalization process developed by the Instituto Mineiro de Gestão das Águas. The results obtained were compared to the RC obtained in regionalization methods of the regularization curve and regionalization of reservoir capacity. The methods that include synthetic series associated to return period presented better performance, with $25 \%$ and $15 \%$ lower overestimate and underestimate means, respectively, and estimated values closer to those that considered the observed data series. Therefore, the use of methodologies to estimate RC, using SS was adequate for the locations without fluviometric monitoring in the Jequitinhonha River Basin.
\end{abstract}

Key words: streamflow, hydrographic basin, management of water resources

\section{Dimensionamento de reservatório para região semiárida pelo uso de séries sintéticas}

RESUMO: A falta de dados fluviométricos nas bacias hidrográficas interfere diretamente nas estimativas da capacidade de reservatórios de regularização, importantes no atendimento das demandas sazonais de água. O objetivo deste estudo foi avaliar o desempenho de metodologias utilizando-se séries sintéticas de vazão (SS) para dimensionar reservatórios de regularização na Bacia do Rio Jequitinhonha. A capacidade do reservatório (CR) foi estimada com e sem a associação ao período de retorno, a partir de diferentes valores de percentagem da vazão média de longo termo, utilizando-se SS obtidas a partir de dados observados e de dados estimados pelo processo de regionalização de vazões desenvolvido pelo Instituto Mineiro de Gestão das Águas. Os resultados obtidos foram comparados à CR obtida nos métodos regionalização da curva de regularização e regionalização da capacidade do reservatório. Os métodos que utilizam as séries sintéticas associadas ao período de retorno apresentaram melhor desempenho, com valores médios de superestimativas e subestimativas menores que 25 e 15\%, respectivamente, estimando valores mais próximos daqueles que consideram a série de dados observados. Desta forma, o uso de metodologias para estimar CR utilizando SS mostrou-se adequado para locais sem monitoramento fluviométrico na Bacia do Rio Jequitinhonha.

Palavras-chave: vazão, bacia hidrográfica, gestão de recursos hídricos 


\section{INTRODUCTION}

Water scarcity occurs mainly due to asymmetry in its distribution, lack of management, and inadequate management of natural resources. In this context, arid and semiarid regions are severely affected, since they present intense rainfalls concentrated in a short period followed by a long drought period (Martins et al., 2018).

The search for temporal and spatial balance between available and demanded water is essential to meet its increasing demand. The use of regularization reservoirs is an alternative for decreasing losses caused by scarcity and potentialize the use efficiency of water resources, making possible water accumulation during the rainy periods and distribution throughout long drought periods (Wang et al., 2013; Xu et al., 2017).

Thus, regularization reservoirs are important to promote a sustainable management of water resources (Li et al., 2010). However, the adequate dimensioning of these structures requires long-term records of fluviometric data (Kuria \& Vogel, 2015), which are incomplete for most hydrographic basins in the world (Loukas \& Vasiliades, 2014).

This limitation of unavailability of streamflow data can be overcome by considering continuum synthetic series of streamflows, which represents an alternative to estimate reservoir capacities.

Therefore, the objective of this study was to evaluate the performance of methodologies based on synthetic series (SS) of streamflow for the dimensioning of regularization reservoirs in the Jequitinhonha River Basin, Brazil.

\section{Material And Methods}

The study was developed for the Jequitinhonha River Basin, Brazil, which cover an area of $70,315 \mathrm{~km}^{2}, 66,319 \mathrm{~km}^{2}$ in the state of Minas Gerais, and $3,996 \mathrm{~km}^{2}$ in the state of Bahia (Gonçalves, 1997). A large part of this basin is in the Semiarid region, which is characterized by a poor perennial river network, with water streamflows in the rainy season or soon after the rainfall events.

The generation of synthetic series for the section of interest (not monitored) was based on the methodology proposed by Rodrigues (2017), using observed streamflow data or regionalized from fluviometric stations in the same hydrologically homogeneous region of the section of interest to generate representative synthetic series for the section.

The study developed by IGAM (2012) classified the whole Jequitinhonha River Basin as a hydrologically homogeneous region. Figure 1 presents the location of the Jequitinhonha River Basin, and fluviometric stations used in the study.

The proposed methodology is presented in Figure 2 and is based on the generation of synthetic series, estimation of the reservoir capacity by methodologies that use these series, and methods that do not use these series for comparisons.

The synthetic series were estimated for the section of interest, according to Eq. 1:

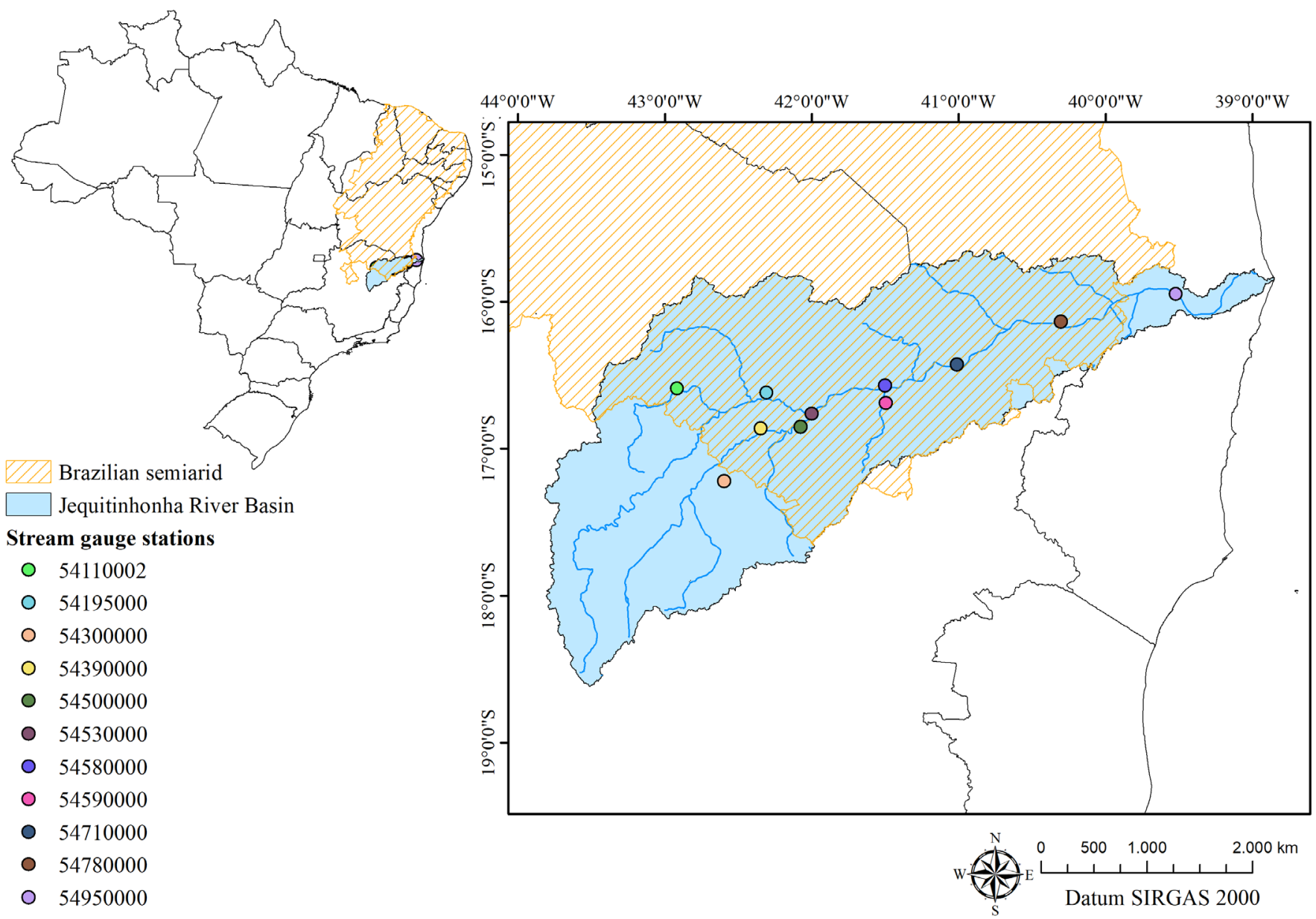

Figure 1. Location of the Jequitinhonha River Basin, Brazil, and fluviometric stations used in the study 


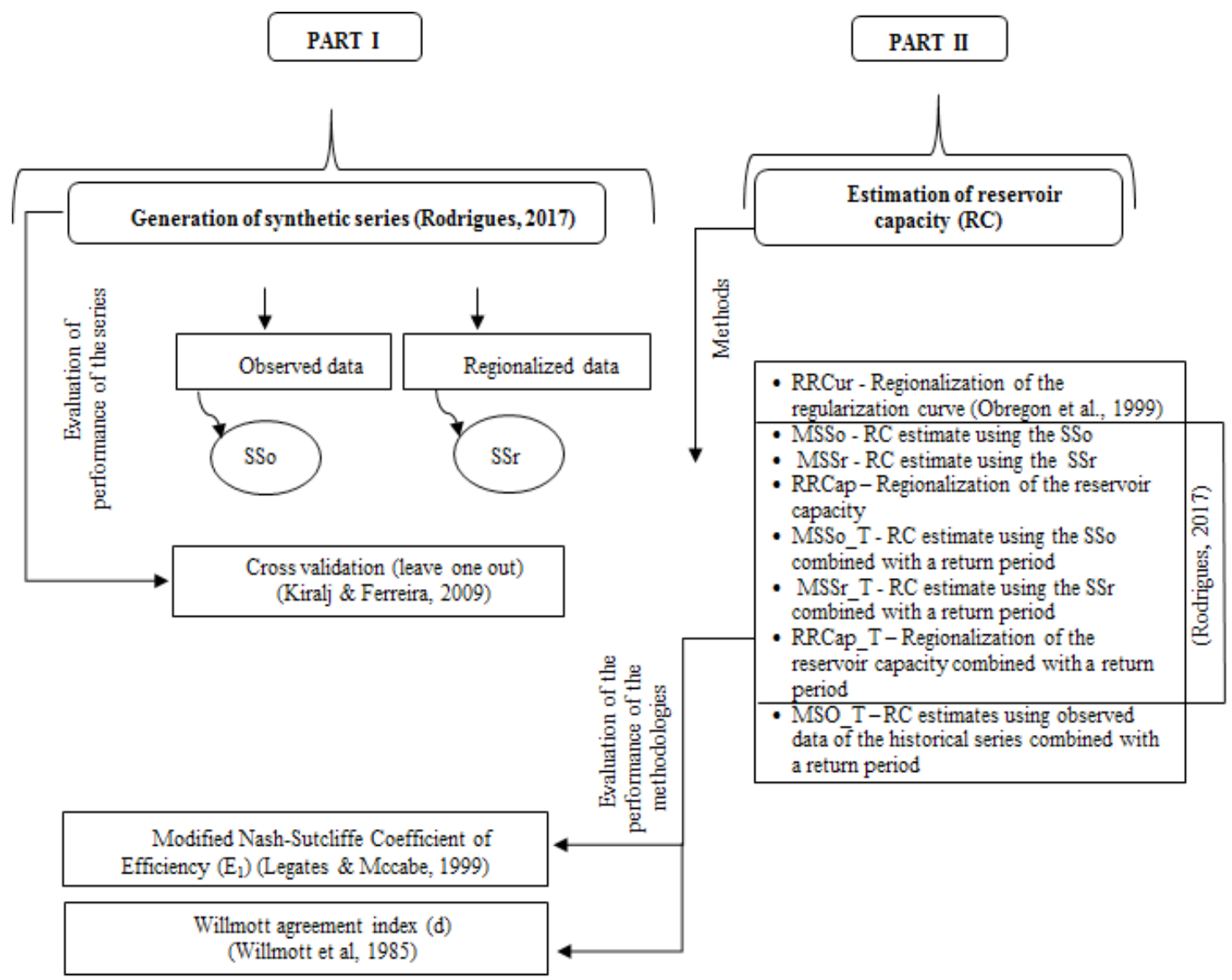

Figure 2. Methodological flowchart$$
\mathrm{Q}_{\mathrm{SI}, \mathrm{d}}=\left\{\frac{\sum_{\mathrm{i}=1}^{\mathrm{n}}\left[\mathrm{q}_{\mathrm{EF}_{\mathrm{i}, \mathrm{d}}}\left(\frac{\mathrm{q}_{\mathrm{mlt}_{\mathrm{SI}}}}{\mathrm{q}_{\mathrm{mlt}_{\mathrm{EF}_{\mathrm{i}}}}}\right)\right]}{\mathrm{n}}\right\} \mathrm{A}_{\mathrm{SI}}
$$

where:

$Q_{S I, d}$ - streamflow of the section of interest in the day $d$, $\mathrm{m}^{3} \mathrm{~s}^{-1}$;

$\mathrm{q}_{\mathrm{EF}_{\mathrm{I}, \mathrm{d}}}$ - specific streamflow of the fluviometric station $\mathrm{i}$ in the day $\mathrm{d}, \mathrm{m}^{3} \mathrm{~s}^{-1} \mathrm{~km}^{-2}$;

$\mathrm{q}_{\mathrm{lt}_{\mathrm{SI}}}$ - specific long-term average streamflow in the section of interest obtained by regionalization studies, $\mathrm{m}^{3} \mathrm{~s}^{-1} \mathrm{~km}^{-2}$;

$\mathrm{q}_{\mathrm{lt}_{\mathrm{EF}_{\mathrm{i}}}}$ - specific long-term average streamflow in the fluviometric station i (observed or regionalized), $\mathrm{m}^{3} \mathrm{~s}^{-1} \mathrm{~km}^{-2}$;

$\mathrm{n}$ - number of streamflow in the gauge station; and,

$\mathrm{A}_{\mathrm{SI}}$ - drainage area of the section of interest, $\mathrm{km}^{2}$.

The synthetic series with $\mathrm{q}_{\mathrm{lt}_{\mathrm{EF}}}$ data of fluviometric stations were termed observed synthetic series (SSo); and the synthetic series with $\mathrm{q}_{\mathrm{It}_{\mathrm{FF}_{\mathrm{i}}}}$ data referring to regionalized data in the stations were termed regionalized synthetic series (SSr). The regionalized data were estimated by the streamflow regionalization process described by IGAM (2012).

The performance of the synthetic series was evaluated using leave-one-out cross validation. This methodology consists in excluding a sample of the dataset and estimate its value using the remaining samples. The estimated value is then compared to the value of the removed sample (Muller \& Thompson, 2016). Thus, each fluviometric station was considered notmonitored and left out to obtain the synthetic series (SSr or SSo) for the section.

The quality of the synthetic series ( $\mathrm{SSr}$ and SSo) was evaluated by comparing the $\mathrm{q}_{1 \mathrm{t}}$ of these series to the qlt of the historical series of observed streamflow (SO) using the relative error (RE), as described in Eq. 2

$$
\mathrm{RE}=\left[\frac{\left(\mathrm{q}_{\mathrm{lt}_{\mathrm{SS}}}-\mathrm{q}_{\mathrm{lt}_{\mathrm{So}}}\right)}{\left(\mathrm{q}_{\mathrm{lt}_{\text {So }}}\right)}\right] 100
$$

where:

$\mathrm{RE}$ - relative error;

$\mathrm{q}_{\mathrm{lt}_{\text {SS }}}$ - specific long-term average streamflow of the synthetic series (SSo or SSr), $\mathrm{m}^{3} \mathrm{~s}^{-1} \mathrm{~km}^{-2}$; and,

$\mathrm{q}_{\mathrm{lt}_{\mathrm{So}}}$ - specific long-term average streamflow of the observed series, $\mathrm{m}^{3} \mathrm{~s}^{-1} \mathrm{~km}^{-2}$.

The reservoir capacity (RC) was estimated based on different methods: regionalization of regularization curve (RRCur), RC estimate using the observed synthetic series (MSSo), RC estimate using the regionalized synthetic series (MSSr), and regionalization of reservoir capacity (RRCap), the latter three can be associated with the return period (MSSo_T, MSSr_T, RRCap_T). RC was also estimated based on the historical data series associated with the return period (MSO_T), which was the reference method due to its less prone conditions to errors related to databases. 
RRCur is commonly used to dimensioning reservoirs in locations without fluviometric data, and RRCap is used for comparisons in the evaluation of methods based on generation of synthetic series.

Four proportions $(0.25,0.50,0.75$, and 1.00$)$ of long-term mean streamflow were used to dimension the regularization reservoirs, which indicate the water potential availability of the hydrographic basin, representing the maximum streamflow that can be regularized.

The dimensioning of regularization reservoir capacity requires the value of the highest volumes of accumulated deficit, calculated by the method of accumulated differences or maximum accumulated deficit. In this method, the accumulated deficit volume is obtained by the highest sum of deficits between the affluent streamflow and the streamflow to be regularized. The most critical period was the one with the highest accumulated deficit and, consequently, higher RC.

Probability density functions (PDF) were used to associate the RC to the different return periods (T) (Kite, 1988), using Eq. 3:

$$
\mathrm{RC}_{\mathrm{T}}=\overline{\mathrm{x}}+\mathrm{ks}
$$

where:

$\mathrm{RC}_{\mathrm{T}}$ - reservoir capacity associated with a return period, $\mathrm{hm}^{3}$;

x - mean accumulated deficit volumes, $\mathrm{hm}^{3}$;

$\mathrm{k}$ - frequency factor, dimensionless; and,

$s$ - standard deviation of the accumulated deficit volumes, $\mathrm{hm}^{3}$.

There is an adequate form to determine the frequency factor for each probabilistic distribution (Kite, 1998).

The highest accumulated deficit volume is obtained for each year for the annual operation rule, showing the number of deficits corresponding to the number of years of synthetic series. PDF are applied for the series related to the numbers of deficits, showing the RC associated to $\mathrm{T}$.

The combined years of the series is analyzed for the pluriannual operation rule, showing only one accumulated deficit volume, which does not allow for the use of PDF. The modified accumulated difference method (MADM), developed by Nunes \& Pruski (2015) was used to obtain several RC associated to different return periods.

The MADM is based on the development of temporal synthetic series in which the number of synthetic series will be equal to the number of years of the period based on the historical series of available streamflows less one, since an accumulated deficit volume will be associated to each series, including the original. The following functions of probability density distribution were analyzed for all deficits: Gumbel, Log-Normal type II, Log-Normal type III, Pearson type III, and Log-Pearson type III.

The regularization curve developed through calculations of several volumes for regularized streamflows relates the regularization degree to the volume required and allows the estimate of RC in locations without monitoring, based on Eq. 4:

$$
\mathrm{RC}=\mathrm{fa} \beta^{\mathrm{b}} \mathrm{Q}_{\mathrm{lt}_{\mathrm{reg}}}
$$

where:

f - factor of conversion for cubic hectometers (0.0864);

$a$ and $b$ - parameters obtained in the regression, dimensionless;

$\beta$ - streamflow fraction to be regularized, dimensionless; and,

$\mathrm{Q}_{\mathrm{lt}_{\text {reg }}}$ - long-term mean streamflow regionalized for the section of interest, $\mathrm{m}^{3} \mathrm{~s}^{-1}$.

The variables to be regionalized in relation to RRCur in the reservoir capacity regionalization proposed by Rodrigues (2017) were altered, with the advantage of associating the RC to the $\mathrm{T}$.

The RC was calculated for each fluviometric station located in the same hydrologically homogeneous region of the section of interest based on the demand. The RC were obtained and regionalized, generating regression equations that associate them to the streamflow equivalent to the rainfall volume in the drainage area of the station less an abstract factor, which is $600 \mathrm{~mm}$ for the Jequitinhonha River Basin (Peq600) (IGAM, 2012), using Eq. 4

$$
\mathrm{Peq}_{600}=\frac{(\mathrm{P}-600) \mathrm{A}}{\mathrm{k}}
$$

where:

Peq600 - streamflow equivalent to the rainfall volume less $600 \mathrm{~mm}\left(\mathrm{~m}^{3} \mathrm{~s}^{-1}\right)$;

$\mathrm{P}$ - mean total annual rainfall in the area, $\mathrm{mm}$;

A - drainage area, $\mathrm{km}^{2}$; and,

k - conversion factor (31536).

The abstract factor is used to encompass part of the rainfall that is not converted into runoff over the hydrographic region due to other process, mainly evapotranspiration (Pruski et al., 2013).

The regression model used was the potential, represented by Eq. 6

$$
\mathrm{RC}_{\mathrm{T}-\mathrm{D}}=\mathrm{cPeq}_{600} \mathrm{~d}
$$

where:

$\mathrm{RC}_{\mathrm{T}-\mathrm{D}}$ - reservoir capacity associated to $\mathrm{T}$ and the demand, $\mathrm{hm}^{3}$; and,

$\mathrm{c}$ and $\mathrm{d}$ - parameters obtained in the potential regression.

The methodologies proposed to estimate RC were evaluated by the modified Nash-Sutcliffe index $\left(\mathrm{E}_{1}\right)$ and Willmott agreement index (d). The RC from the observed data series were adopted as reference to evaluate the methodologies.

The coefficient of efficiency of $\mathrm{E}_{1}$ proposed by Legates \& McCabe Junior (1999) indicates the distance of the estimated data by proposed method to the mean observed data (Ale et al., 2012); it varies from - $\infty$ to 1 (Zhang et al., 2007) (Eq. 7). An 
$\mathrm{E}_{1}$ of 1 indicates a perfect combination between the estimated and observed data.

The Willmott agreement index (d) (Willmott et.al, 1985) varies from zero (no agreement) to 1 (perfect agreement), based on Eq. 8

$$
\begin{gathered}
\mathrm{E}_{1}=1-\left[\frac{\sum_{\mathrm{i}=1}^{\mathrm{n}}\left|\mathrm{RC}_{\mathrm{SO}_{\mathrm{i}}}-\mathrm{RC}_{\mathrm{SS}_{\mathrm{i}}}\right|}{\sum_{\mathrm{i}=1}^{\mathrm{n}}\left|\mathrm{RC}_{\mathrm{SO}_{\mathrm{i}}}-\overline{\mathrm{RC}_{\mathrm{SO}_{\mathrm{i}}}}\right|}\right] \\
\mathrm{d}=1-\frac{\sum_{\mathrm{i}=1}^{\mathrm{n}}\left(\mathrm{RC}_{\mathrm{SO}_{\mathrm{i}}}-\mathrm{RC}_{\mathrm{SS}_{\mathrm{i}}}\right)^{2}}{\sum_{\mathrm{i}=1}^{\mathrm{n}}\left(\left|\mathrm{RC}_{\mathrm{SS}_{\mathrm{i}}}-\overline{\mathrm{RC}_{\mathrm{SO}_{\mathrm{i}}}}\right|+\left|\mathrm{RC}_{\mathrm{SO}_{\mathrm{i}}}-\overline{\mathrm{RC}_{\mathrm{SO}_{\mathrm{i}}}}\right|\right)^{2}}
\end{gathered}
$$

where:

$\mathrm{RC}_{\mathrm{SO}_{\mathrm{i}}}$ - reservoir capacity estimated for the fluviometric station $\mathrm{i}$, based on the original series of streamflows, $\mathrm{m}^{3} \mathrm{~s}^{-1} \mathrm{~km}^{-2}$;

$\mathrm{RC}_{\mathrm{SS}_{\mathrm{i}}}$ - reservoir capacity estimated for the fluviometric station $\mathrm{i}$, based on the synthetic series, $\mathrm{m}^{3} \mathrm{~s}^{-1} \mathrm{~km}^{-2}$;

$\mathrm{RC}_{\mathrm{SO}_{\mathrm{i}}}$ - mean observed values of reservoir capacity in the fluviometric stations, $\mathrm{m}^{3} \mathrm{~s}^{-1} \mathrm{~km}^{-2}$; and,

$\mathrm{n} \quad$ - number of fluviometric stations considered.

The historical series of the Brazilian Water Agency (Agência Nacional de Águas - ANA) fluviometric stations in the basin were used. The regionalized $\mathrm{Peq}_{600}$ and $\mathrm{q}_{\mathrm{lt}}$ were obtained from IGAM (2012). The period from 1970 to 2005 was used based on the analysis of data availability. Years with flaws higher than $5 \%$ were discarded.

Table 1 shows the codes of the stations used in the study, their geographical coordinates, and respective areas of contribution.

Table 1. Codes, geographical coordinates, and areas of contribution of fluviometric stations of the Jequitinhonha River Basin, Brazil

\begin{tabular}{|cccr|}
\hline Code & Latitude & \multicolumn{1}{c|}{ Longitude } & \multicolumn{1}{c|}{$\begin{array}{r}\text { Area } \\
\left(\mathbf{k m}^{2}\right)\end{array}$} \\
\hline 54110002 & $16^{\circ} 59^{\prime} 49^{\prime \prime} \mathrm{S}$ & $42^{\circ} 35^{\prime} 89^{\prime \prime} \mathrm{W}$ & 4100 \\
\hline 54195000 & $16^{\circ} 61^{\prime} 78^{\prime \prime} \mathrm{S}$ & $42^{\circ} 30^{\prime} 86^{\prime \prime} \mathrm{W}$ & 23815 \\
\hline 54300000 & $17^{\circ} 22^{\prime} 03^{\prime \prime} \mathrm{S}$ & $42^{\circ} 59^{\prime} 79^{\prime \prime} \mathrm{W}$ & 1252 \\
\hline 54390000 & $16^{\circ} 86^{\prime} 01^{\prime \prime} \mathrm{S}$ & $42^{\circ} 34^{\prime} 83^{\prime \prime} \mathrm{W}$ & 11000 \\
\hline 54500000 & $16^{\circ} 85^{\prime} 41^{\prime \prime} \mathrm{S}$ & $42^{\circ} 06^{\prime} 19^{\prime \prime} \mathrm{W}$ & 16230 \\
\hline 54530000 & $16^{\circ} 75^{\prime} 88^{\prime \prime} \mathrm{S}$ & $42^{\circ} 00^{\prime} 38^{\prime \prime} \mathrm{W}$ & 39394 \\
\hline 54580000 & $16^{\circ} 57^{\prime} 23^{\prime \prime} \mathrm{S}$ & $41^{\circ} 50^{\prime} 23^{\prime \prime} \mathrm{W}$ & 45819 \\
\hline 54590000 & $16^{\circ} 68^{\prime} 96^{\prime \prime} \mathrm{S}$ & $41^{\circ} 49^{\prime} 23^{\prime \prime} \mathrm{W}$ & 1283 \\
\hline 54710000 & $16^{\circ} 43^{\prime} 17^{\prime \prime} \mathrm{S}$ & $41^{\circ} 01^{\prime} 30^{\prime \prime} \mathrm{W}$ & 53298 \\
\hline 54780000 & $16^{\circ} 13^{\prime} 45^{\prime \prime} \mathrm{S}$ & $40^{\circ} 30^{\prime} 60^{\prime \prime} \mathrm{W}$ & 63300 \\
\hline 54950000 & $15^{\circ} 94^{\prime} 29^{\prime \prime} \mathrm{S}$ & $39^{\circ} 52^{\prime} 34^{\prime \prime} \mathrm{W}$ & 67769 \\
\hline
\end{tabular}

\section{Results AND Discussion}

The results of $\mathrm{q}_{\mathrm{lt}}$ of the synthetic series and their respective relative error percentages in relation to the original data and the $\mathrm{q}_{\mathrm{lt}}$ of the original series are shown in Figure 3.

The $\mathrm{q}_{\mathrm{lt}}$ of the SSo and SSr were, in general, close to the observed values, without expressive difference between them, with mean relative error close to $10 \%$ for SSo and $12 \%$ for SSr. The $\mathrm{q}_{1 \mathrm{t}}$ of the synthetic series presented no trend, with oscillating errors between overestimates and underestimates (Figure 3).

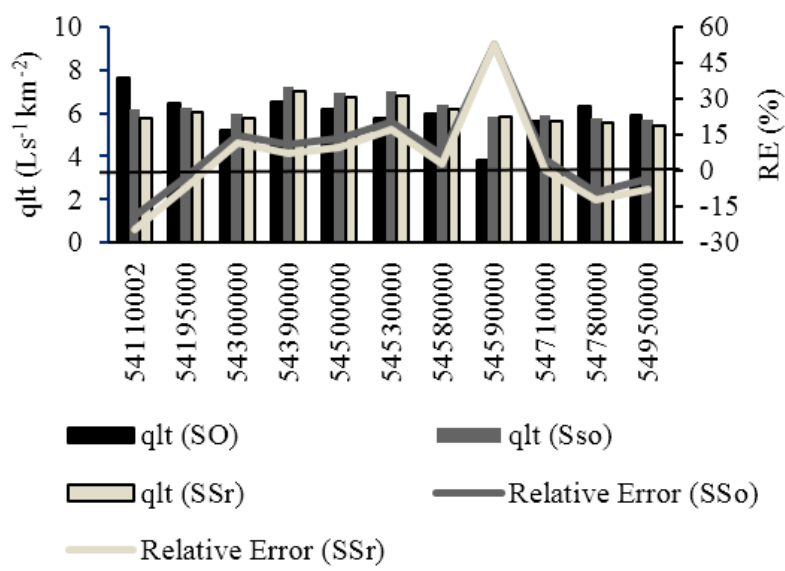

SO - Observed historical series of streamflow; SSO - Observed synthetic series of streamflow; SSr - Regionalized synthetic series of streamflow

Figure 3. Long-term mean streamflow $\mathrm{q}_{1 \mathrm{t}}$ of observed historical series of streamflow (SO), observed synthetic series of streamflow (SSo), regionalized synthetic series of streamflow (SSr), and relative error (RE) of two synthetic series from each fluviometric station of the Jequitinhonha River Basin, Brazil

The higher error for the original series, which reached approximately -20\% (stations 54110002) and 50\% (stations 54590000 ) in the two synthetic series, are explained by the flaws in the regionalization process of the IGAM (2012), in which the regionalized $\mathrm{q}_{\mathrm{lt}}$ estimate also presented higher residue percentage for these stations.

The RC was calculated by the proposed methodologies for all stations, and was exemplified by the fluviometric stations 54580000 (Figure 4), representative of the other stations.

The RC obtained for the different $\beta$ and $\mathrm{T}$ showed that the methodologies RRCur, MSSo, MSSr, and RRCap do not follow the growth of RC estimated by MSO_T as the T increases because they are not associated to T. Thus, the analysis of these methodologies shows the occurrence of underestimates and overestimates, mainly for RRCur due to more inconsistent values in relation to the original series in the $\beta$ of 0.5 . The methodology RRCap is superior to RRCur, but exhibited considerable underestimates in this station, lower than those of the MSSo and MSSr methodologies, which stood out with lower inconsistencies than the reference method, mainly in the $\beta$ of 0.75 .

Moreover, the methodologies MSSo and MSSr have better applicability than the RRCap, since after a regionalization study and generation of synthetic series the application of the maximum accumulated deficit method is required to obtain the RC (Rodrigues, 2017). The use of RRCap requires the regionalization of the obtained $\mathrm{RC}$ after the application of maximum accumulated deficit method, which generates the equation for estimate the RC for the section. Thus, the use of synthetic series for RC estimation has good applicability, with more representative estimates.

Despite the satisfactory results of MSSo and MSSr, methodologies that consider the $\mathrm{T}$ are more representative, since the data vary as the $\mathrm{T}$ is modified. Methodologies that use $\mathrm{T}$ are more complex, requiring the application of MADM and PDF, but the RC calculation associated with the frequency factor is more indicated because it enables the forecast of largemagnitude hydrological events, important for the development of hydrological projects. 


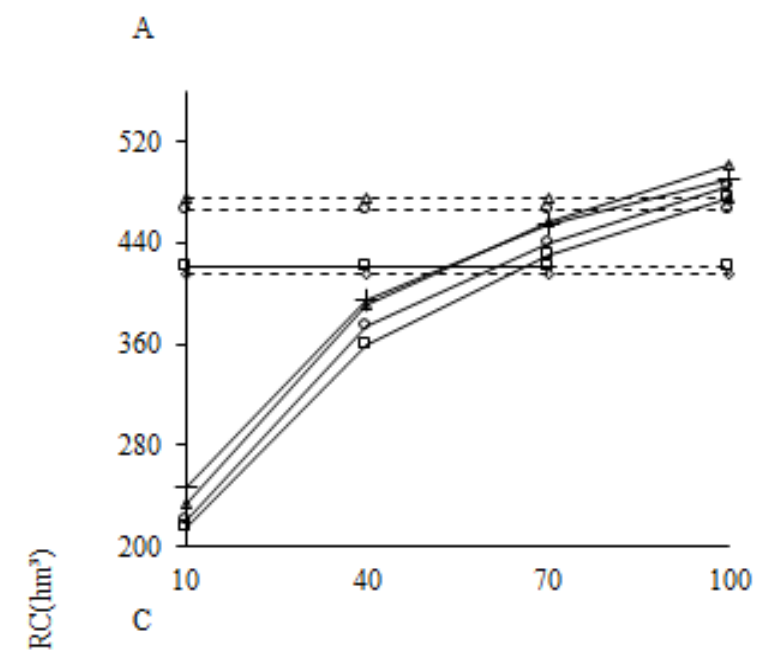

B
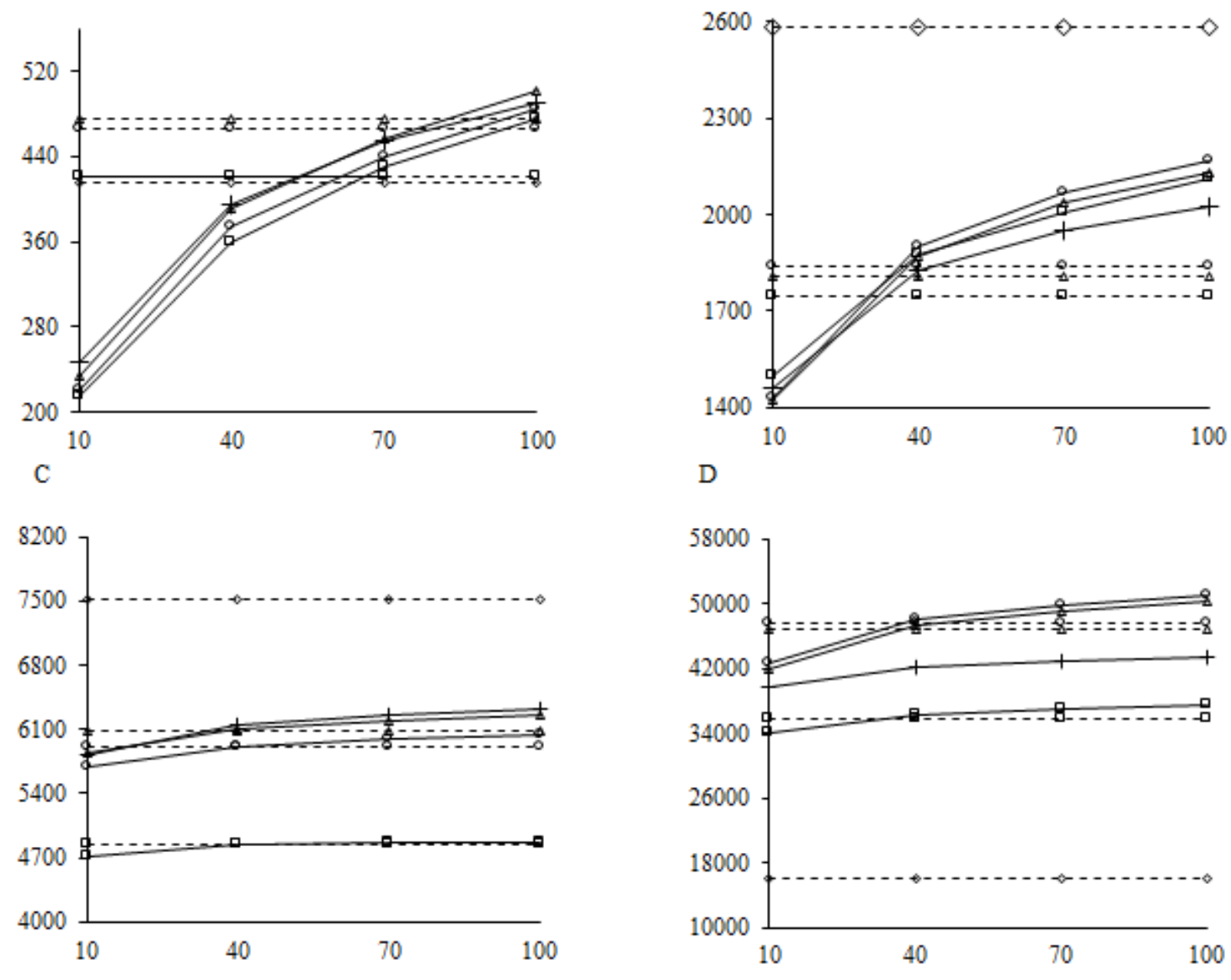

Return period (years)

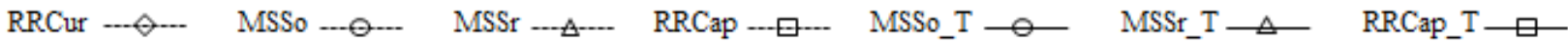

RRCur - Regionalization of Regularization Curve; MSSo - RC estimate using the observed synthetic series; MSSr - RC estimate using the regionalized synthetic series; RRCap Regionalization of reservoir capacity; MSSo_T, MSSr_T, RRCap_T - MSSo, MSSr, and RRCap methods associated to a return period

Figure 4. Reservoir capacity (RC) in different return periods with $\beta$ of 0.25 (A), 0.50 (B), 0.75 (C), and 1.00 (D) for the stations 54580000

The MSSo_T and MSSr_T are among the methodologies that use $\mathrm{T}$ that had the best results, except for $\beta=0.5$, and $\beta=1.0$, for $\mathrm{T}=70$ years and $\mathrm{T}=100$ years, in which the RRCap_T method had values closer to the HDS-T. However, the RRCap_T method presented the highest underestimate values of RC in the highest $\beta$, providing a poor safety for the reservoir to be dimensioned.

Different from the RRCap_T, the MSSo_T and MSSr_T methodologies have a tendency of overestimating the RC of the station, except for $\beta=0.75$. These overestimates are not desirable, but ensure a higher safety of water supply to the reservoir.

Figure 5 shows the mean maximum errors (RE) for each method and fluviometric station.

The results were consistent to those associated to the RC of station 54580000 (Figure 4), where relative errors of methodologies that did not consider the $\mathrm{T}$ were higher for overestimates and underestimates.

The mean relative errors of the methodologies that did not consider the $\mathrm{T}$ for each station showed that the use of RRCur had higher relative errors in most stations, and was responsible for the highest underestimates in nine stations, and highest overestimates in six, with maximum errors above $100 \%$ in six stations, which characterizes it as the less adequate among the studied methods for reservoir dimensioning.
The use of RRCap resulted in the highest errors in overestimates and underestimates in three and two stations, respectively, mainly for overestimates, which were generally high and presented high values of maximum errors, which reached more than $180 \%$ in three stations, as found by Rodrigues (2017).

Therefore, MSSo and MSSr had better performance for the estimates of RC, among the methods without use of T. These methods presented small differences, with similar relative errors, and deviations that favor the system safety, with higher discrepancies in the overestimates (Figure 5A).

Among the models that consider the T, RRCap_T had, in general, the highest amplitude of mean relative errors of the stations (Figure 5B). Moreover, this method presented 170\% higher maximum overestimates in two stations. This confirms the predictive advantage of RC with the use of methodologies that use synthetic series.

The methods MSSr_T and MSSo_T presented similar statistical results for most stations, with mean overestimates and underestimates lower than $25 \%$ in seven stations and lower than $15 \%$ in eight stations, respectively, denoting higher overestimating tendency. The overdimensioning have environmental, economic, and social disadvantages, but ensures a higher water safety. 
A

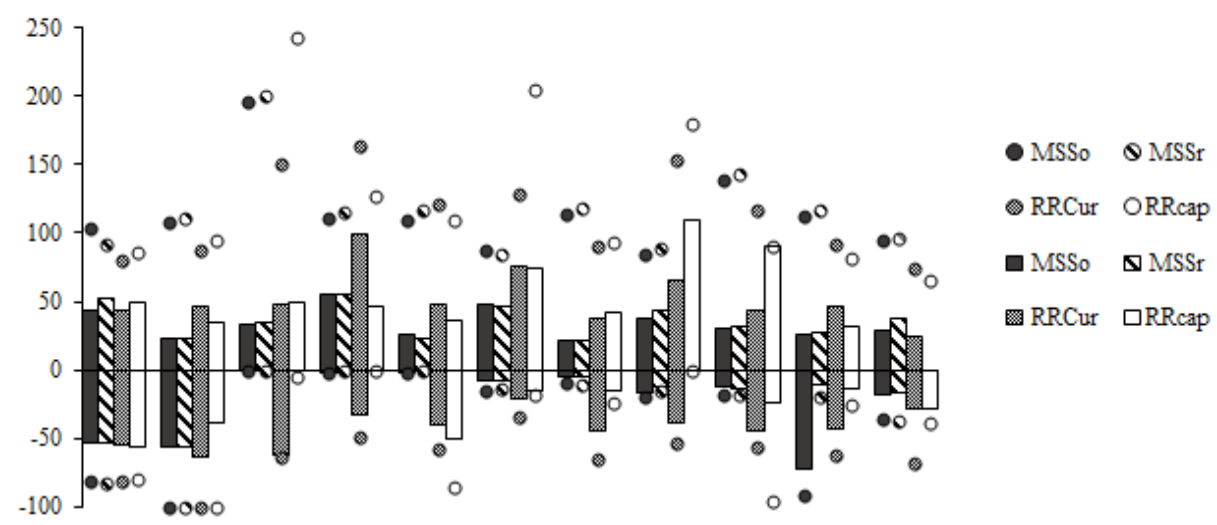

일

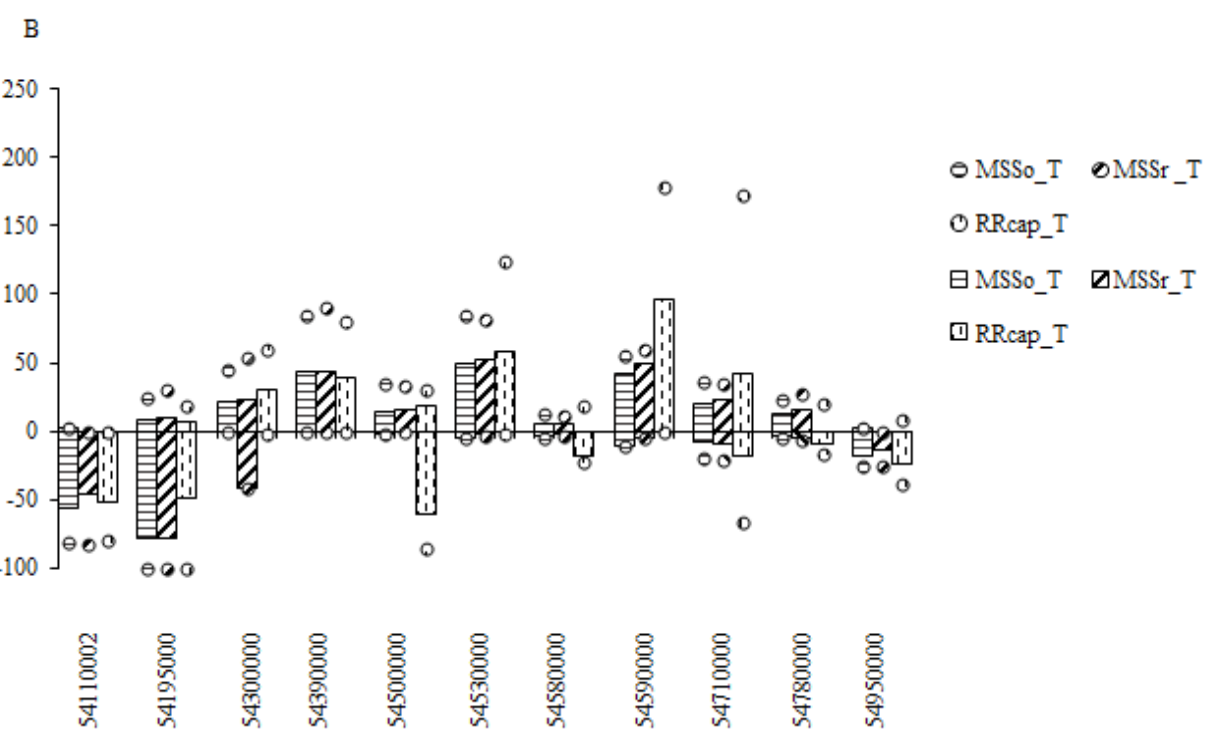

RRCur - Regionalization of regularization curve; MSSo - RC estimate using the observed synthetic series; MSSr - RC estimate using the regionalized synthetic series; RRCap - Regionalization of reservoir capacity; MSSo_T, MSSr_T, RRCap_T - MSSo, MSSr, and RRCap methods associated to a return period

Figure 5. Mean (columns) and maximum (points) relative errors (RE) of each fluviometric station for the methodologies without (A) and with (B) return period (T)

An optimal reservoir dimensioning is between the critical overdimensioning (high project cost) and underdimensioning (need for water rationing during dry periods) (Tucci, 2012) situations. Therefore, a more adequate dimensioning requires analyses of risks and valuation of the safety water, thus using preferably high-reliability methods in situations of high risk of insufficient water supply, even when MSSociated with a lower cost and proportion of flooded areas. Semiarid regions present high spatial and temporal rainfall variabilities (Cabral et al., 2016); thus, implementing reservoirs is needed due to the strong impacts of water scarcity, since the water demand in these regions are not met (Hauschild, 2000)

Considering the analyses, the methods of estimate of RC that do not consider the $\mathrm{T}$ present lower performance and should be avoided; among the methods that are associated to a frequency factor, RRCap_T present lower efficiency; and the methods that include synthetic series are the most indicated. These results are consistent with those presented by Rodrigues (2017), who evaluated these methodologies for dimensioning reservoirs for a sub-basin of the Paracatu River.

Figures 6 and 7 show the values of $E_{1}$ and d, respectively, for each $\beta$, considering a mean of all $\mathrm{T}$ analyzed. Only the results referring to methodologies that use $\mathrm{T}$ were included, due to

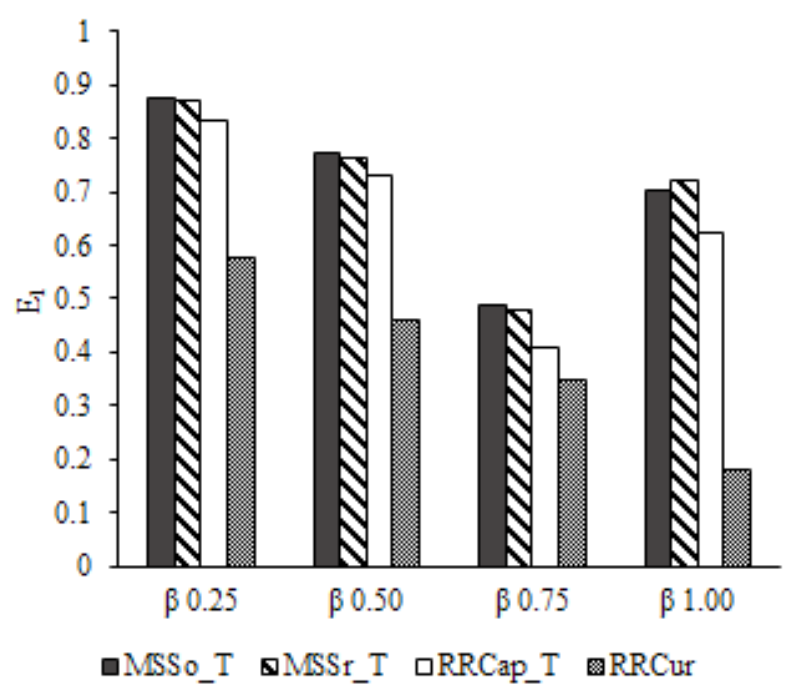

RRCur - Regionalization of regularization curve; MSSo_T - RC estimate using the observed synthetic series combined with a return period; MSSr - RC estimate using the regionalized synthetic series combined with a return period; RRCap_T - Regionalization of reservoir capacity combined with a return period

Figure 6. Nash Sutcliffe mean coefficient of efficiency $\left(E_{1}\right)$ for each $\beta$ value in four methods for estimating reservoir capacity

their superiority in relation to others, and to the RRCur, being the mainly used in studies involving dimensioning of reservoirs. 


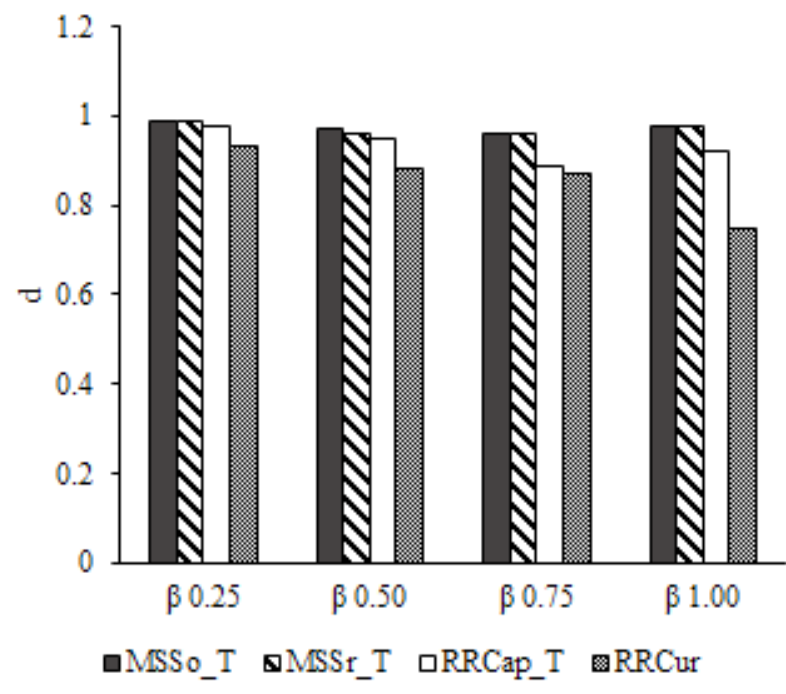

RRCur - Regionalization of regularization curve; MSSo_T - RC estimate based on the observed synthetic series combined with a return period; MSSr - RC estimate based on the regionalized synthetic series combined with a return period; RRCap_T - Regionalization of reservoir capacity combined with a return period

Figure 7. Mean Willmott agreement index (d) for each $\beta$ value in four methods for estimating reservoir capacity

According to Silva et al. (2008), when $\mathrm{E}_{1}$ is higher than 0.75 , the performance of the model is good, 0.36 to 0.75 is acceptable, and lower than 0.36 is unacceptable.

The method RRCur presented lower $\mathrm{E}_{1}$, as expected, being unacceptable for $\beta$ of 0.75 to 1.00 . The method RRCap_T had acceptable results for $\beta$ of $0.5,0.75$, and 1.00 , and good only for $\beta$ of 0.25 . In addition, this method presented lower coefficient than the MSSo_T and MSSr_T for all $\beta$ values. The methods MSSo_T and MSSr_T presented $\mathrm{E}_{1}$ higher than 0.75 for $\beta$ of 0.25 to 0.5 , and acceptable results for higher $\beta$ values.

The results of the Willmott agreement index (d), which indicates the distancing of observed values in relation to the estimated by the standard model, showed better performance for the methods MSSo_T and MSSr_T, with higher indexes to all $\beta$ values. Moreover, the method RRCur showed lower values than the other methods.

Thus, the methodologies MSSo_T and MSSr_T had better performances, and can be used for any $\beta$ value. This denotes that regionalized data are efficient in generating synthetic series and, consequently, to be used to dimension streamflow regularization reservoirs without presenting differences in the use of values of the original series.

The use of methods that aggregate improvements to estimate RC is important, since they enable regional social, economic, and environmental development, mainly in semiarid regions, in which water scarcity is a major concern of the population.

However, despite the many benefits, the construction of reservoirs generates several impacts that should be measured, analyzed, and discussed, considering mainly their purposes.

\section{Conclusions}

1. Methods that include synthetic series are adequate to dimension regularization reservoirs in locations with no or insufficient fluviometric data, in the Jequitinhonha River Basin, Brazil.
2. The methods that associate synthetic series to a return period (MSSo_T and MSSr_T) showed better performances than those that do not consider this frequency factor in the estimates of reservoir capacity.

\section{ACKnow ledgements}

This research was supported by the Coordenação de Aperfeiçoamento de Pessoal de Nível Superior (CAPES) Finance Code 001, and Conselho Nacional de Desenvolvimento Científico e Tecnológico (CNPq) grant number 134506/2016-2, Brazil.

\section{Literature Cited}

Ale, S.; Bowling, L. C.; Owens, P. R.; Brouder, S. M.; Frankenberger, J. R. Development and application of a distributed modeling approach to assess the watershed-scale impact of drainage water management. Agricultural Water Management, v.107, p.23-33, 2012. https://doi.org/10.1016/j.agwat.2012.01.003

Cabral, S. L.; Campos, J. N. B.; Silveira, C. da S. Pereira, J. M. R. $\mathrm{O}$ intervalo de tempo para uma máxima previsibilidade da precipitação sobre o semiárido brasileiro. Revista Brasileira de Meteorologia, v.31, p.105-113, 2016. https://doi.org/10.1590/0102778631220130034

Gonçalves, R. do N. Diagnóstico ambiental da Bacia do Rio Jequitinhonha: Diretrizes gerais para a ordenação territorial. Salvador: IBGE, 1997. 64p.

Hauschild, M., Döll, P. Water Use in Semi-arid Northeastern Brazil - Modeling and Scenario Analysis. Report A0003, Center for Environmental Systems Research, University of Kassel, Kassel, 2000. 80p.

IGAM - Instituto Mineiro de Gestão das Águas. Estudo de regionalização de vazão para o aprimoramento do processo de outorga no Estado de Minas Gerais. 1.ed. Belo Horizonte: IGAM, 2012. 415p.

Kite, G. W. Frequency and risk analyses in hydrology. Littleton: Water Resources Publications, 1988. 257p.

Kuria, F.; Vogel, R. Uncertainty analysis for water supply reservoir yields. Journal of Hydrology, v.529, p.257-264, 2015. https://doi. org/10.1016/j.jhydrol.2015.07.025

Legates, D. R.; Mccabe Junior, G. J. Evaluating the use of "goodnessof-fit" measures in hydrologic and hydroclimatic model validation. Water Resources Research, v.35, p.233-241, 1999. https:/doi. org/10.1029/1998WR900018

Li, X.; Guo, S.; Liu, P.; Chen, G. Dynamic control of flood limited water level for reservoir operation by considering inflow uncertainty. Journal of Hydrology, v.391, p.124-132, 2010. https://doi. org/10.1016/j.jhydrol.2010.07.011

Loukas, A.; Vasiliades, L. Streamflow simulation methods for ungauged and poorly gauged watersheds. Natural Hazards and Earth System Sciences. v.14, p.1641-1661, 2014. https://doi. org/10.5194/nhess-14-1641-2014

Martins, M. A.; Tomasella, J.; Rodriguez, D. A.; Alvalá, R. C. S.; Giarolla, A.; Garofolo, L. L.; Siqueira Júnior, J. L.; Paolicchi, L. T. I. C.; Pinto, G. L. N. Improving drought management in the Brazilian semiarid through crop forecasting. Agricultural Systens, v.160, p.121-130, 2018. https://doi.org/10.1016/j.agsy.2017.11.002 
Muller, M. F.; Thompson, S. E. Comparing statistical and processbased flow duration curve models in ungauged basins and changing rain regimes. Hidrology and Earth System Sciences, v.20, p.669-683, 2016. https://doi.org/10.5194/hess-20-669-2016

Nunes, A. de A.; Pruski, F. F. Improving the determination of reservoir capacities for drought control. Stochastic Environmental Research and Risk Assessment, v.29, p.183-191, 2015. https://doi. org/10.1007/s00477-014-0950-z

Obregon, E.; Tucci, C. E.; Goldenfun, J. A. Regionalização de vazões com base em séries estendidas: bacias afluentes à Lagoa Mirim, RS. Revista Brasileira de Recursos Hídricos, v.4, p. 57-75, 1999. https://doi.org/10.21168/rbrh.v4n1.p57-75

Pruski, F. F.; Nunes, A. de A.; Pruski, P. L.; Rodriguez, R. del G. Improved regionalization of streamflow by use of the streamflow equivalent of precipitation as an explanatory variable. Journal of Hydrology, v.476, p.52-71, 2013. https://doi.org/10.1016/j.jhydrol.2012.10.005

Rodrigues, N. C. Dimensionamento da capacidade de reservatórios de regularização de vazões utilizando séries sintéticas. Viçosa: UFV, 2017. 73p. Tese Doutorado

Silva, P. M. de O.; Mello, C. R. de; Silva, A. M. da; Coelho, G. Modelagem da hidrógrafa de cheia em uma bacia hidrográfica da região Alto Rio Grande. Revista Brasileira de Engenharia Agrícola e Ambiental, v.12, p.258-265, 2008. https://doi.org/10.1590/S1415-43662008000300006
Tucci, C. E. M. Hidrologia: Ciência e aplicação. 4.ed. Porto Alegre: UFRGS, 2012. 943p.

Wang, X.; Huang, G.; Lin, Q.; Nie, X.; Cheng, G.; Fan, Y.; Li, Z.; Yao, Y.; Suo, M. A stepwise cluster analysis approach for downscaled climate projection - A Canadian case study. Environmental Modelling \& Software, v.49, p.141-151, 2013. https://doi. org/10.1016/j.envsoft.2013.08.006

Willmott, C.J.; Ackleson, S. G.; Davis, R. R.; Feddema, J. J.; Klink, K. M.; Legates, D. R.; Odonnel, J.; Rowe, C. M. Statistics for evaluation and comparison of models. Journal of Geophysical Research, Washington, v.90, n.C5, p.8995-9005, 1985. https://doi. org/10.1029/JC090iC05p08995

Xu, B.; Boyce, S. E.; Zhang, Y.; Liu, Q. Stochastic programming with a joint chance constraint model for reservoir refill operation considering flood risk. Journal of Water Resources Planning and Management, v.143, p.1-11, 2017. https://doi.org/10.1061/(ASCE) WR.1943-5452.0000715

Zhang, H. G.; Fu, S. H.; Fang, W. H.; Imura, H.; Zhang, X. C. Potential effects of climate change on runoff in the Yellow River Basin of China. Transactions of the American Society of Agricultural Engineers, v.50, p.911-918, 2007. https://doi. org/10.13031/2013.23155 